\title{
PARADIGMA BARU FIQH PEREMPUAN (Studi Analisis atas Gender Mainstreaming Omid Safi dalam Agenda Muslim Progressive)
}

\author{
Mohammad Thoha \\ (Program Pascasarjana IAIN Sunan Ampel Surabaya, jln. A. Yani 117 Surabaya, \\ email:Thoha@yahoo.com)
}

\begin{abstract}
Abstrak
Omid Safi dan kawan-kawan dengan label Muslim Progressive mengusung tiga agenda besar, yakni mewujudkan keadilan sosial, kesetaraan jender, dan pemahaman terhadap pluralisme. Dengan metode multiple critique, Omid Safi mengkritisi kejumudan para ultra Konservatif yang selalu menyalahkan Yahudi, Kristen, dan bahkan umat Muslim yang tidak sepaham dengan mereka. Demikian pula kritik di sisi ini diarahkan kepada kaum neo Konservatif yang menjadikan teks begitu kaku dan rigit serta ditafsirkan apa adanya. Sementara di sisi lain Muslim Progressive juga mengkritisi kaum Muslim liberal yang menjadikan modernitas sebagai kiblat utama tujuan hidup mereka dengan mengenyampingkan tradisi keislaman sebagai landasan moral dan pikiran. Muslim Progressive digagas untuk mengawinkan kedua sisi tersebut. Tulisan ini menampilkan tawaran Muslim Progressive dalam agenda kesetaraan jender, yang menekankan pada paradigm baru figh perempuan. Muslim Progressive memaknai figh sebagai interpretasi syari'ah. Dengan demikian, figh harus diformulasikan sesuai dan seimbang dengan tuntutan zaman. Teks al-Qur'an dan Sunnah yang dijadikan landasan lahirnya produk figh tidak harus dipahami sebagaimana fuqahâ $\hat{}^{-}$memahaminya saat itu. Perkembangan zaman, kebutuhan, dan tujuan semestinya senantiasa menjadi 'illah yang menyertai perumusan hukum saat ini.
\end{abstract}

\begin{abstract}
Omid Safi and his friends with the label of Muslim Progressive bring three big agendas, those are forming social justice, gender equality, and the understanding of pluralism. By using multiple critique method, Omid Safi criticizes the stagnancy of some ultraconservative that always blame
\end{abstract}


Yahudi, Kristen, and even Moslem that are not in line with them. Furthermore this critique is oriented to neoconservative that make the text so rigid, and it is also translated its reality. While, on the other hand, Moslem Progressive also criticize liberal Moslem that make modernity as their main orientation by ignoring Islamic tradition as moral fundamental and thought. Moslem Proggressive is formed to join both views. This article describes the offer of Progressive Moslem in gender equality agenda, stressing on the new paradigm of woman figh. They give the meaning of figh as the interpretation of syari'ah. Therefore, figh has to be formulated suitable and balanced to the era demand. The Qur'an text and Sunnah must become the fundamental of the existing of figh product that is not a must to understand as fuqahâ $\hat{a}^{\prime}$ understood it at that time. The development of era, the need and the purpose should always become 'illah following the formula of the Islamic law at the present.

\section{Kata Kunci}

Muslim Progressive, multiple critique, jender, figh.

\section{Pendahuluan}

Membaca pemikiran Omid Safi tentang jender, tentu saja tidak bisa dilepaskan dari konsep pemikirannya secara utuh tentang Muslim Progressive. Hal ini dikarenakan kesetaraan jender yang diusungnya merupakan satu bagian dari tiga visi (agenda) utama pemikiran Omid Safi tentang Muslim Progressive, di samping keadilan sosial, dan pluralisme. Oleh karena itu untuk membahas kegelisahan akademik dan metode serta pendekatan yang digunakannya juga memerlukan pembacaan yang utuh dari seluruh agenda Muslim Progressive. ${ }^{1}$ Setidaknya, Omid Safi sebagai penggagas label Muslim Progressive telah banyak melibatkan koleganya untuk menuangkan

\footnotetext{
${ }^{1}$ Dalam hal ini setidakya Safi telah memulai gagasan besarnya dengan membentuk forum ilmiah yang digagasnya sejak tahun 2006 dan membentuk suatu wadah dengan nama Muslim Progressive. Untuk mendapatkan gambaran lebih lanjut dari hangatnya proses ilmiah tersebut, baca Omid Safi, “ Introduction: The Time They Are a Changing- A Muslim Quest for Justice, Gender Equality, and Pluralisme", dalam Omid Safi (ed), Muslim Progressive on Justice, Gender and Pluralisme (Oxford: Oneworld, 2003), hlm. 18-21.
} 
bersama pemikiran mereka tentang keadilan sosial, kesetaraan jender, dan pemahaman terhadap realitas plural. ${ }^{2}$

Demikian pula, sebelum membahas pemikiran Omid Safi tentang jender sebagai bagian dari agenda Muslim Progressivenya, maka dirasa perlu kiranya untuk juga menyinggung terlebih dahulu pengertian dari Muslim Progressive itu sendiri dan membaca latar belakang akademis dan sosiokultural Omid Safi sebagai penggagas konsep tersebut. Sebenarnya Omid Safi sendiri mengatakan bahwa konsep Muslim Progressive tidak harus dimaknai sebagai konsep yang sudah selesai dan baku. Apa yang yang digagasnya bersama temanteman koleganya hanyalah sebatas tangkapan mereka dari manifesto Muslim Progressive yang begitu lentur dan cair untuk terus didiskusikan. ${ }^{3}$

\section{Omid Safi: Pengembaraan Intelektual dan Setting Sosiokultural}

Omid Safi adalah pemikir Muslim berkebangsaan Amerika Serikat berdarah Iran. Oleh karena itu, pemikirannya sepertinya dipengaruhi motivasinya untuk mempertemukan Islam dengan "kesalahpahaman" Barat, dalam hal ini Amerika. Sudah menjadi maklum bahwa Islam oleh Barat selalu dikonotasikan sebagai agama yang keras, kaku, tidak menghargai hak perempuan, tidak mengedepankan hak azazi manusia, dan fanatik. Omid Safi ingin menyadarkan Barat bahwa Islam sangat ramah lingkungan, sangat menjunjung hak asasi manusia, menghormati perempuan, dan mentoleransi pluralisme. Oleh karena itu, Islam harus ditampilkan dengan wajah yang demokratis, adaptif, pluralis, dan progresif.

Karir akademisnya dimulai dari North Carolina University sebagai alamamater utamanya. Di sini ia meraih posisi asisten professor, sebelum akhirnya pada tahun 2010 dianugerahi gelar sebagai guru besar penuh (professor) pada kajian studi keislamam

\footnotetext{
2 Mereka adalah Omid Safi (sekaligus editor), Khaled Abu el Fadl, Farid Esack, Ahmet Karamustafa, Ebrahim Moosa, Tazim R. Kasam (para kontributor dengan tema keadilan sosial (social justice), Sa'diyya Shaikh, Kecia Ali, Scott Siraj al-Haqq Kugle, Gwendolyn Zohara Simmon (kontributor dengan tema jender), Amir Hussain, Amina Wadud, Ahmad S. Mausolli, Mercia Hermansen, dan Farish A. Noor (kontributor dengan tema pluralisme). Ibid., hlm. vii..

3 Safi, "Introduction", hlm. 7.
} 
klasik dan kontemporer. ${ }^{4}$ Selain di perguruan tinggi tersebut, Omid Safi meraih penghargaan sebagai pengajar dan dosen tamu favorit dari beberapa perguruan tinggi lain di Amerika, seperti Colgate University, Duke University, dan Harvard University. Di Harvard, ia membidani lahirnya kajian pluralism dan memimpin Islamic Studies: American Academy of Religion. 5 Di luar kampus, Omid Safi juga memimpin perkumpulan sufi (misticism) bagi Muslim Amerika.

Pluralisme menjadi fokus kajian utamanya. Sebagai contoh, dalam hal pemilihan presiden Amerika, ia dengan tegas mendukung calon presiden Barck Obama, meskipun Obama adalah calon presiden kulit hitam pertama di Amerika dan kebetulan berdarah Afrika. Tentang hal ini Omid safi berkata, "we need more than a president for judio Christian America. We need a president for the United State of America". 6

Karya-karya ilmiah Omid Safi adalah Progressive Muslims on Justice, Gender and Pluralisme (sebagai editor) (Oxford: Oneworld, 2003), The Politic of Knowledge in Premodern Islam, (Chapel Hill: UNC Press, 2006), Voice of Change Vol 5 in the vol series Voice of Islam (editor), (Praeger, 2007), Memories of Muhammad: Why The Prophet Matters, (Harpen One, 2009), Ibince of Amirican Muslim, (New York: Hipporcrenc Books, 2005).

Selain menulis buku, Omid Safi juga banyak memberikan kontribusi berupa artikel lepas yang dimuat di beberapa media seperti The New York Times, Nesweek, Washington Post, PBS, NPR, NBC, CNN dan media internasional lainnya. ${ }^{7}$

\section{Muslim Progressive: Apa dan Bagaimana?}

Diskursus tentang prooresif tidak akan menemukan ujungnya. Berangkat dari kata dasar progress yang dimaknai sebagai kemajuan, para pemikirnya selalu menawarkan konsep yang terus diperbarui dan justru diperdebatkan. Sering sekali progresif dimaknai dengan kemajuan yang berujung pada lahirnya kebebasan yang justru menciptakan libralisme yang tidak terkendali. Sebagai contoh, dalam hal sejarah Ebrahim Moosa mengilustrasikan bahwa sejarah akan

\footnotetext{
${ }^{4}$ www.religionnews.com//.../omidsafi. diakses 5 Oktober 2012.

${ }^{5}$ www.haffingtonepost.com./omed-safi. diakses 5 Oktober 2012

${ }^{6}$ www.religionnews.com//../omidsafi. diakses 5 Oktober 2012

7 Ibid.
} 
terus bergerak dan maju sampai pada titik yang tak terhindarkan, dari sistem tribal ke teokrasi terus bergerak ke arah aristokrasi, dan terus bergerak menuju kapitalisme, dan baru berhenti pada demokrasi liberal. ${ }^{8}$ Seakan untuk menghindari perdebatan dari makna progress itu sendiri, Omid Safi kemudian merumuskan makna progress dengan memberikan syarat bahwa sesuatu dianggap maju apabila ia memberikan perubahan ke arah yang lebih baik, lebih bermanfaat, dan lebih berdaya guna bagi kehidupan umat manusia dan dunia secara lebih luas. ${ }^{9}$ Selanjutnya, Omid Safi merumuskan bahwa sesuatu disebut lebih baik bilamana telah memenuhi dua kata kunci, yaitu keadilan (al-'adl/justice) dan kebaikan atau keindahan (alihssân). Kedua kata kunci ini kemudian diterjemahkan pada keadilan sosial, kesetaraan jender, dan pluralisme..$^{10}$

Meskipun demikian Omid Safi tetap terbuka untuk tidak mengatakan bahwa pemaknaan progresif yang dikemukakannya adalah yang paling benar. Seraya mengkritisi mereka yang menganggap bahwa Muslim Progressive adalah yang paling benar, paling cerdas, paling maju, Omid Safi justru mengatakan bahwa Muslim Progressive tidak boleh elitis, tetapi tidak boleh juga berdiam diri hanya sebatas menjadi kritikus. Inilah mengapa Omid Safi tidak memakai istilah Muslim kritis (critical Muslim). Karena menurut Safi kritikus diidentikkan dengan golongan yang hanya berkeluh kesah dan mengkritisi, tetapi tetap duduk santai di tempatnya dengan tanpa berbuat apa-apa. ${ }^{11}$

\section{Metode Kritik Muslim Progressive}

Metode yang digunakan Omid Safi dalam merumuskan konsepnya tentang Muslim Progressive adalah metode multiple critique. Dalam makna yng sangat sederhana multple critique ini dapat diartikan sebagai kritik ganda, di mana kita sebagai umat Muslim

\footnotetext{
8 Selengkapnya dapat dibaca pada Ebrahim Moosa, "Transitions In The Progress of Civilization: Theorizing History, Practie, and Tradition", dalam Vincent Cornell dan Omid Safi (ed), Voices of Change (Westport: Praeger Publisher, 2007), hlm. 115.

9 Tentang hal ini bisa dibaca di Omid Safi, "Challeges and Oppuortunities for The Progressive Muslim in North America” Muslim Public Affairs Journal, (Januari 2006), hlm. 77.

10 Safi, “ Introduction”, hlm. 6.

11 Ibid., hlm. 18.
} 
harus mampu mengkritisi diri sendiri di satu sisi dan juga harus mampu mengkritisi Barat dalam sisi yang lain. Kritik ganda juga berbasis penggunaan pendekatan beragam arah (a multi-headed approach based) yang didasarkan pada kritik simultan terhadap beragam komunitas dan wacana di mana kita terlibat langsung di dalamnya. ${ }^{12}$

Kritik ganda didasarkan pada gagasan yang sangat sederhana. Omid Safi mengatakan bahwa setiap manusia yang lahir tanpa dibedakan Muslim-non Muslim, laki-laki perempuan, ras apa pun, warna kulit apa pun, suku apa pun, dan seterusnya, memiliki nilai yang sama, yaitu sama-sama dibekali dengan nilai kesucian ruh Tuhan.13 Oleh karena itu, semua manusia berhak mendapatkan perlakuan yang sama, keadilan, kesetaraan, dan kesempatan yang sama tanpa harus dibedakan jenis agama, kelamin, suku bangsa, ras, dan lain sebaginya. Dengan ini pula, segala bentuk ketidakadilan, diskriminasi, penjajahan, perbudakan, dan segala ketimpangan kemanusian harus dikritisi dan diperbaiki. Dalam kesempatan lain, Safi mengatakan bahwa justru sering dijumpai adanya perlakuan tidak adil, diskriminatif, otoriter, dan tidak demokratis yang justru dilakukan umat Muslim dan justru mengatasnamakan Islam. ${ }^{14}$ berikut:

Sebagai contoh penggunaan multiple critique dapat dijelaskan

1. Muslim Progressive mengkritisi pemaknaan teks hukum Islam yang diskrimatif terhadap perempuan yang kerap digunakan kaum fundamentalis ortodoks, sementara di sisi lain Muslim Progressive juga menolak ekploitasi perempuan yang dilakukan Barat dengan jargon kesetaraan jender dan sebagainya ${ }^{15}$

\footnotetext{
12 Ibid., hlm. 2.

13 Ibid., hlm. 3.

14 Safi, "Challeges and Opportunities", hlm.80.

15 Dalam hal ini, Safi mengkritisi pola pikir kaum Oreintalis yang secara membabi buta menganggap bahwa Islam telah membatasi hak perempuan dengan adanya perbedaan dengan kaum laki-laki dalam masalah poligami dan larangan Islam bagi kaum perempuan untuk menikah dengan laki-laki non Muslim, sementara larangan tersebut tidak berlaku bagi kaum laki-laki. Mereka dalam pandangan Muslim Progressive tidak membaca asas manfaat (al-maqâsid al-syar'iyyah) yang terkandung dari datangnya ketentuan tersebut. Baca William Montgomery Watt, Islamic Fundamentalism and Modernity (London dan New York: Routledge, 1988), hlm. 114.
} 
2. Di satu sisi Muslim Progressive mengkriti persekusi kelompok minoritas di negara-negara Muslim, sementara di sisi lain Muslim Progressive juga menyoal kebijakan luar negeri Amerika yang selalu agresif mengadu domba mereka.

3. Muslim Progressive sangat mengkritisi dan mendebat orang-orang Islam yang tidak henti-hentinya membenci dan memusuhi Barat (Muslim Westernmophobes), seperti Usamah bin Laden, Ayman alZawahiri, atau Sulaiman Abu Ghayt. Namun di sisi lain, Muslim Progressive juga mengecam orang-orang Barat yang tidak hentihentinya membenci Islam (Western Islamophobes), seperti Bernard Lewis, Samuel P. Huntington, Daneil Pipe, atau Robert Spencer

4. Dalam satu sisi, Muslim Progressive tidak setuju dengan gerakan Wahabi dan neo Wahabi, akan tetapi di sisi yang lain Muslim Progressive juga tidak sepaham dengan gerakan Islam sekular. ${ }^{16}$

Selanjutnya dengan bahasa yang lebih gamblang, Omid Safi dengan multiple critique-nya tersebut mengkritisi kaum yang disebutnya sebagai ultrakonservatif atau mereka yang tidak hanya anti Barat, Yahudi, dan Kristen, akan tetapi mereka juga memusuhi umat Muslim yang tidak memiliki paham dan keyakinan seperti mereka. Di sisi lain, arah kritik Muslim Progressive juga diarahkan pada golongan liberal karena menjadikan modernitas (yang cenderung berdamai dengan kolonialisme dan imperialism) sebagai tujuan utamanya dan dibela mati-matian. Sebaliknya, Muslim Progressive memandang bahwa kolonialisme dan imperialisme harus dikritisi. Dalam pandangan Omid Safi, modernitas dengan segala arogansinya telah berhasil mencuri ideologi kaum Muslim dengan menjadikannya sebagai berhala yang selalu dipuja, ditularkan, didiskusikan, dan bahkan dijadikan muara regenerasi dari masa ke masa. ${ }^{17}$ Dengan metode multiple critique inilah Muslim Progressive mencoba mengawinkan tradisi Islam yang kaya dan beragam di satu sisi dengan modernisasi di sisi yang lain, serta mencoba merumuskan yang terbaik dari hasil perkawinan tersebut.

16 Disarikan dari Omid Safi, "I and Thou in A Fluid Word: Beyond Islam versus the West," dalam Voice of Change, eds. Vincent Cornell and Omid Safi, (Westport: Praeger Publisher, 2007), hlm.199-210.

17 Safi, “ Introduction”, hlm. 4. 
Untuk menjalankan metode multiple critique sebagaimana dijelaskan di atas, Omid Safi memberikan beberapa prasyarat yang harus dilakukan untuk mencapai Muslim Progressive yang sebenarnya. Prasyarat tersebut di antaranya sebagai berikut: Pertama, keterlibatan yang utuh dalam tradisi keislaman. Seseorang yang sekedar hanya berapologi dengan jargon keadilan, kesetaraan jender, pluralisme, dan sebagainya, namun ia tidak pernah terlibat langsung dan utuh dalam tradisi keislaman, maka ia bukanlah bagian dari Muslim Progressive. Seorang Muslim Progressive sangat menghormati tradisi. Oleh karena itu, ia harus memiliki pondasi bangunan keilmuan agama ('ulûm al-dîn) yang bagus dan kokoh sebagai bagian dari tradisi keislaman, namun demikian tradisi itu juga harus dikritisi. Jangan sampai didogmakan sehingga tidak bisa diubah sedikit pun dari bentuk aslinya. Kondisi kekinian, zaman, dan problematika umat Muslim akan senantiasa menggiring tradisi keislaman tersebut beradaptasi dengan umat Muslim itu sendiri. Namun demikian, Muslim Progressive juga tidak setuju dengan paham sekular yang ingin mencerabut dan menghilangkan tradisi keislaman tersebut. Muslim Progressive memandang tradisi sebagai a tradition in becoming, sebuah tradisi yang akan terus berkembang dan mencari bentuk yang sesuai dengan zamannya. ${ }^{18}$

Kedua, hindari sikap apologis. Permasalahan yang dihadapi umat Muslim sangat kompleks dan terus berkembang. Hal ini tentu saja memerlukan upaya yang tidak sederhana untuk menjawabnya. Sikap pragmatisme dan apologatif sering dijadikan pilihan utama oleh sebagian besar kaum Muslim. Tidak jarang kita jumpai jawaban, ungkapan, dan bahkan pendapat yang disandarkan pada nilai kebenaran absolut Islam, padahal sebenarnya itu jauh dari makna kebenaran yang sebenarnya. Omid Safi menyebut kaum pragmatis ini dengan sebutan Islam pamflet, yaitu kalangan yang berupaya menyelesaikan masalah yang sangat rumit dengan merujuk kepada dalil ajaran Islam yang sangat sedernaha dan monolitik. Mereka sering berkata, "dalam ajaran islam disebutkan..." atau "Islam mengatakan..." atau sering juga, "menurut al-Qur'an...", dan sebagainya. Pernyataan tersebut sebenarnya adalah gambaran kemalasan mereka dalam berfikir (ber-ijtihâd). Mereka tidak pernah

18 Ibid., hlm.5-9. 
menyadari bahwa untuk menjawab permasalahan yang sangat rumit dan kompleks diperlukan ijtihâd, dan bahkan mungkin jihâd intelektual yang sungguh-sungguh untuk mengatasi permasalahan kontemporer berlandaskan tradisi Islam yang kaya, plural, dan majemuk. ${ }^{19}$

Ketiga, penyelarasan antara visi dan langkah konkret. Visi dan aksi (misi) menjadi dua hal yang harus hadir bersama. Visi yang bagus tetapi tidak disertai pelaksanaan yang konkret dalam pandangan Safi akan segera menjadi sesuatu yang tidak relevan, akan hilang bersama waktu. Demikian pula aksi yang dilakukan tanpa visi yang jelas adalah sesuatu yang sudah gagal sejak semula. Dalam rumusan Muslim Progressive, visi dan aksi diarahkan pada keinginan dan tindakan sosial. Tindakan sosial yang dimaksud semisal membela kaum tertindas, membela hak perempuan, menegakkan hak asasi manusia, menyerukan perdamain, di mana semua itu sudah menjadi tradisi keislaman dan tidak pernah membatasi ras, suku bangsa, etnik, bahasa, kaya miskin, golongan, dan sebagainya. ${ }^{20}$

Keempat, menyandarkan pada aspek humanisme dan adab. Jika humanisme diposisikan sebagi ruh filosofisnya, maka adab diposisikan sebagai kode etik hubungan lahiriyah manusia. Orang yang tidak memiliki spirit humanisme dan ditopang dengan adab yang buruk, akan sangat mudah mengkafirkan, memusyrikkan, dan membid'ahkan kelompok lain yang tidak sama dengan mereka. Pada kondisi seperti ini Omid Safi menwarkan tasawuf sebagai prototipe perpaduan humanism dan adab. Seorang sufi akan memiliki moral etika secara interpersonal dan di sisi lain akan menularkan etika baik tersebut pada orang lain secara komunal. Dalam hal ini Omid Safi mengatakan al-tashawwufu kulluhu al-adab."21

Kelima, keterbukaan pada sumber pengetahuan sekunder. Seorang Muslim Progressive tidak boleh merasa cukup dengan mengetahui al-Qur'an dan Hadits sebagai sumber primer saja. Lebih dari itu ia harus juga memiliki kekayaan referensi pembanding. Misalnya, seseorang harus seimbang dalam membaca pemikiran-

19 Disarikan dari pemikiran Omid Safi dalam, Omid Safi, "Progressive Islam in America," transkrip wawancara dengan Krista Tippet dalam Speakingof Fath, 28 Juli 2005, hlm. 2.

20 Ibid.

21 Safi, “ Introduction”, hlm. 13-14. 
pemikiran Jalaludin Rumi dan Ibn 'Arabi, Plato dan Ibn Sina, Chomsky dan Abu Darr, Ghandy dan Arundhati, Robert Fisk dan Edward Said, Dalai Lama dan Eloie Wisel, Bob Dylan dan Bob Marley, dan sebagainya ${ }^{22}$

\section{Kesetaraan Jender sebagai Bagian dari Agenda Muslim Progressive}

Pada dasarnya ada tiga agenda besar (misi) dari Muslim Progressive yang diusung Omid Safi dan kawan-kawannya sebagai mana disebut sebelumnya. Ketiga agenda tersebut adalah, pertama mewujudkan keadilan sosial yang tidak membatasi strata sosial, ras, golongan, suku bangsa, agama dan sekat sosial apa pun; kedua mempropagandakan kesetaraan jender dalam setiap aspek kehidupan, baik dalam sisi ekonomi, sosial, budaya, agama, pendidikan, hukum, dan seterusnya; ketiga menerima pluralitas sebagai kenyataan yang harus dihormati dan dijalankan. ${ }^{23}$

Kesetaraan jender dalam pandangan Omid Safi tidak selalu dikonotasikan pada diskriminasi perempuan, akan tetapi dehumanisasi laki-laki juga akan menjadi permasalahan jender yang patut diselesaikan. Dalam hal ini, isu jender tidak hanya berputar pada isu jibab, hijab, dan atribut feminis lainnya. ${ }^{24}$ Akan tetapi jender lebih difokuskan pada kajian eksistensi perempuan di ruang publik yang tentu saja mungkin berbeda antara satu daerah dengan daerah yang lain. Gerak publik tersebut meliputi kesempatan yang sama antara laki-laki dan perempuan untuk belajar, berkarya, berorganisasi, dan seterusnya. ${ }^{25}$ Yang perlu dicatat dari pemikiran Omid Safi adalah kesetaraan dan keadilan jender harus diberikan pada kaum wanita bukan sebagai hadiah atau belas kasihan pada mereka, melainkan karena mereka adalah bagian dari umat manusia yang memang memiliki hak yang melekat atas semua yang semestinya mereka dapatkan. ${ }^{26}$

22 Ibid., hlm.14-15.

23 Ibid.

${ }^{24}$ Afaf Lutfi al-Sayyid Marsod, "Perempuan Wira Usaha" dalam Feminisme dan Islam: Perspektif Hukum dan Sastra, ed. Mai Yamani, terj. Purwanto (Jakarta: Nuansa, 2000), hlm. 54

25 Baca lebih lanjut Valentine M. Moghadam, Modernizing Women: Gender and Social Change in The Midle East (Boulder dan London: Lynne Rienner Publisher, 1993), hlm. 14.

26 Safi, “ Introduction", hlm. 10-11. 
Sa'diyya Shaik, ${ }^{27}$ salah seorang kontributor Muslim Progressive, berpendapat bahwa kesetaraan jender sebenarnya telah terjadi sejak periode awal Islam. Rasulullah sering sekali mendelegasikan 'A' isyah untuk mengajarkan materi-materi tertentu dalam ajaran Islam, atau sebaliknya sahabat perempuan memiliki akses yang sama dengan sahabat laki-laki untuk bertanya, berdiskusi, dan menerima ajaran langsung dari Nabi. Jika, pada kemudian waktu terjadi diskriminasi jender, maka hal itu dikarenakan adanya penafsiran yang tidak sempurna dari teks al-Qur'an dan Hadits berdasarkan kepentingan kaum tertentu, sehingga posisi perempuan selalu dimarjinalkan. ${ }^{28}$ Sistem perbudakan dan diskriminasi laki-laki atas perempuan semestinya sudah ditinggalkan bersama berlalunya sistem kolonialisme dan imprialisme. ${ }^{29}$

Perbedaan antropologis dan budaya tidak harus mengkaburkan kesetaraan jender yang memang menjadi hak dasar semua umat manusia. Boleh jadi suatu daerah berbeda tradisi, akan tetapi perlu diingat bahwa naluri kemanusiaan akan tetap melekat di mana pun. Dalam ruang publik mungkin saja fisik perempuan mendapatkan keterbatasan bergerak, akan tetapi empati, emosi, dan imajinasi, mereka tetap harus dipertimbangkan. Dalam hal pengasuhan anak, memilih arah pendidikan keluarga, menentukan domisili tempat tinggal dan seterusnya, perempuan (istri) memiliki kesempatan yang sama dengan laki-laki (suami). Karena itu semua adalah hak dasar manusia. ${ }^{30}$

Feminisme dan maskulinitas adalah bagian dari budaya dan antropologis. Setiap daerah memiliki kaedah tersendiri tentang batasan keduanya. Sebagai contoh, hijâb dan jilbab yang diterapkan oleh suku Arab adalah upaya menutupi aurat atau melindungi kaum

27 Seorang Muslimah berkebangsaan Afrika Selatan dan berdarah India. Kandidat Doktor di Departemen of religion at Tample University. Fokus kajiannya adalah studi keislaman tentang feminisme, al-Qur'an, dan sufisme. Safi (ed), Muslim Progressive, hlm. $x$.

28 Sa'diyya Shaik, "Transforming Feminim: Islam, Women, and Gender Justice" dalam Muslim Progressive on Justice, Gender, and Pluralism, ed. Omid Safi, (Oxford: Oneworld, 2003), hlm. 148.

${ }^{29}$ Alwi Shihab, Islam Inklusif: Menuju Sikap Terbuka dalam Beragama (Bandung: Mizan, 1999), hlm. 179. Baca juga Isma'il Raji al-Faruqi, al-Tawhid: Its Implications for Thought and Life (Riyad: International Islamic Publishing House, 1995), hlm. 183.

30 Shaik, "Transforming Feminism", hlm. 150. 
perempuan dari godaan seksual, di samping juga bagian dari budaya Arabisme. Oleh karena itu, cara dan metode jilbab dan hijâb tidak harus diterapkan persis seperti apa yang diterapkan di Arab. Bisa saja di daerah lain memakai cara lain untuk melindungi keamaan perempuan. ${ }^{31}$ Sekali lagi pendekatannya adalah antropologis dan budaya. ${ }^{32}$

Dewasa ini justru kita sering menyaksikan keberhasilan perempuan memegang jabatan publik dan justru dari sisi penilain umum melebihi keberhasilan kaum laki-laki dalam jabatan yang sama pada periode sebelumnya. Oleh karena itu, semestinya tidak lagi ada keraguan terhadap kemampuan perempuan untuk memangku berbagai jabatan publik. ${ }^{33}$

Memang sering kali masyarakat kita belum bisa membedakan antara feminisme dan jender. Perlu diketahui sebenarnya bahwa ketika perempuan dikaitkan dengan feminisme, maka itu tidak lebih hanya membicarakan perempuan dari sisi fisik yang memang asasinya berbeda dan diciptakan tidak sama dengan laki-laki. ${ }^{34}$ Akan tetapi, jika sudah menyinggung hal jender, maka konotasinya harus bergeser pada pembacaan kondisi psikologis, rasio, intelegensi, hasrat, dan imajinasi yang tentu saja semua manusia memilikinya tanpa harus dibedakan laki-laki dan perempuan. ${ }^{35}$ Pergeseran

\footnotetext{
${ }^{31}$ Ibid, hlm.152.

32 Baca Ratna Saptari dan Brigitte Holzner, Perempuan Kerja dan Perubahan Sosial: Sebuah Pengantar Studi Perempuan (Jakarta: Pustaka Utama Grafiti, 1997), hlm. 89.

33 Shaik, "Transforming Feminism", hlm. 154

${ }^{34}$ Gerakan feminsme di sini adalah gerakan kesadaran akan posisi perempuan yang rendah di masyarakat, dan keinginan untuk mengubah dan memperbaiki keadaan tersebut. Gerakan ini melahirkan tiga aliran yang berbeda dalam paham feminisme. Ketiga aliran tersebut adalah: (1) feminisme radikal yang berpandangan bahwa struktur masyarakat dilandaskan pada hubungan hierarki dan seksualitas berdasarkan jenis kelamin, di mana laki-laki diposisikan menduduki strata sosial yang tinggi dan berhak mendapatkan jabatan kepemimpinan di masyarakat, sementara perempuan diposisikan sebagai pemenuhan kebutuhan seksualitas; (2) feminisme liberal, yang berkeyakinan bahwa setiap laki-laki dan perempuan memilki hak mengembangkan kemampuan dan rasionalitasnya secara optimal; (3) feminisme sosialis,yang berpendapat bahwa dominasi kaum laki-laki adalah berkaitkan dengan kapitalis, aliran ini bertentangan dengan dua aliran sebelumnya. Lebih jelasnya baca Saptari dan Holzner, Perempuan Kerja, hlm. 48-54.

35 Naomi Wolf, Geger Gender, terj. Omi Intan Naomi (Yogyakarta: Pustaka Semesta Press, 1999), hlm. 335
} 
pradigma feminisme ke jender inilah yang menjadi pekerjaan Muslim Progressive dan harus terus diupayakan. ${ }^{36}$

Sejatinya, perempuan telah berhasil memainkan peran sosial yang lebih berat dibandingkan laki-laki. Peran ganda dan sulit (difficult double commitment) yang harus dijalankan perempuan menuntut keberhasilan yang sama dari dua belah sisi, yakni di satu sisi perempuan harus mampu menjadi ibu rumah tangga yang baik, yang berhasil menyiapkan segala kebutuhan rumah tangga untuk suami dan anak-anakanya, di sisi yang lain, di luar rumah ia dituntut juga untuk memerankan diri sebagai lambang harmonisasi keluarga yang harus tampil elegan, anggun, dan menampilkan kewibawaan keluarga, di samping juga tidak jarang masih ditambah beban tugas dan profesi lainnya di tengah publik. Peran ganda inilah yang telah dengan gemilang dimainkan oleh sarjana Muslimah kita yang telah berhasil dengan prestasi akademis dan sosial, namun tetap bijaksana sebagai ibu rumah tangga. ${ }^{37}$

Sebagai contoh, dewasa ini kita banyak menyaksikan keberhasilan sarjana Muslimah yang telah berhasil menawarkan pradigma penafsiran teks agama yang lebih memberikan ruang gerak lebih besar pada kaum perempuan. Mereka, di antaranya, adalah Amina Wadud Muhsin, seorang pemikir perempuan berkebangsaan Afrika dengan karyanya Qur'an and Women: Rereading the Sacret Text from a Woman's Perspective; Fatima Mernissi seorang sosiolog Maroko dengan gerakannya The Veil and the Male Elite telah menawarkan relasi yang lebih harmonis antara laki-laki dan perempuan; dan Karamah, seorang praktisi hukum berkebangsaan Amerika, yang telah berusaha mewarnai hukum dengan sentuhan jender. ${ }^{38}$

\section{Pradigma Baru Fiqh Perempuan}

Teks al-Qur'an dan sunnah merupakan domain yang paling sulit ditafsirkan ulang, setidaknya itu menjadi garapan yang berat bagi gerakan Muslim Progressive. Selama ini teks-teks syarî́ah diterjemahkan dan diimplementasikan apa adanya tanpa mengaitkan dengan kondisi zaman, lokus, budaya, dan antropologis yang ada. Dalam hal ini dapat dicontohkan, teks tentang hukum potong tangan,

36 Shaik, "Transforming Feminism", hlm. 155.

37 Ibid, hlm. 155-157.

38 Ibid, hlm. 158. 
kewajiban berjilbab, dan memakai hijab dipahami harus sesuai dengan apa yang dilaksanakan pada masa Nabi. ${ }^{39}$

Muslim Progressive berpandangan bahwa hukum Islam harus dipahami dengan pradigama baru. Di mana hukum itu lahir tidak bisa dilepaskan dengan 'illah yang menyertainya. Termasuk dari 'illah adalah kondisi zaman, maksud, dan kepentingan atau tujuan dan penyebab dari terjadinya sesuatu sebagai objek hukum. Urgensi hukum adalah tercapainya kemaslahatan sosial sebagai maqâsid alsyarî'ah. Oleh karena itu bisa saja produk figh akan berubah dari masa ke masa. Sebagai contoh Imâm Abû Hanifah tidak mewajibkan adanya wali atau persetujuan wali bagi perempuan bâligh yang hendak menikah, sementara Imâm al-Syâfi'î mewajibkannya. Kereka berdua hidup dalam zaman yang terpaut jauh sekitar satu abad. ${ }^{40}$

Contoh lain, larangan bagi perempuan untuk beraktifitas di luar rumah semestinya perlu dikaji ulang. ${ }^{41}$ Dengan menyitir beberapa pemikiran Azizah al-Hibri, seorang praktisi hukum di Amerika, Kacia Ali mengatakan bahwa perempuan bebas memilih pekerjaan yang disukainya di luar rumah. Perempuan bebas menerima atau menolak lamaran seorang laki-laki, sebebas laki-laki menentukan pilihan jodohnya. Demikian pula, dalam kehidupan rumah tangga perempuan bebas mendelegasikan tugas rumah tangganya pada orang lain. Memang ada kodrat yang melekat pada diri mereka yang tidak bisa diwakilkan, seperti hamil, melahirkan, dan menyusui. Akan tetapi kodrat itu tidak harus dimaknai keterbelakangan perempuan dibandingkan laki-laki.42

Dalam kasus lain, semisal seks, istri dicenderungkan harus pasrah dan mengalah pada kehendak suami. Dalam hal ini, fuqahấ

39 Kecia Ali, "Progressive Muslim and Islamic Jurisprudence: The Necessity for Critical Engagement with Marriage and Devorce Law" dalam Muslim Progressive on Justice, Gender, and Pluralism, ed. Omid Safi (Oxford: Oneworld, 2003), hlm. 163.

${ }^{40} \mathrm{Ibid}, \mathrm{hlm} .168-169$.

41 Lebih lanjut baca E.A. Boerenbeker, "Wanita dalam Hukum Waris Adat" dalam Peranan dan Kedudukan Wanita Indonesia, ed. Maria Ulfah Subardio dan T.O. Ihromi, (Yogyakarta: Gajahmada University Press, 1994), hlm. 232.

42 Kecia Ali, "Progressive Muslim", hlm. 164. Di negara-negara Arab, khususnya Lebanon, ditemukan akademisi Universitas Amerika Bairut (AUB) bahwa 2 dari 1 guru besar terdiri dari perempuan, dan 5 dari 9 dosen muda adalah perempuan. Lihat Jean Said Makdisi, "Mitologi Kemodernan: Perempuan dan Demokrasi di Lebanon" dalam Feminisme dan Islam, ed. Mai Yamani, hlm. 351. 
jarang sekali menulis tentang hak perempuan dalam hal kebutuhan seksulitas secara transparan. Hanya al-Ghazâlî di antara yang sedikit membahasnya lebih terbuka. Sebenarnya, menurut al-Ghazâlî, sebagaimana dikutip Scott Sirajul Haq Kugle, perempuan (istri) berhak untuk mengkomunikasikan kebutuhan seknya kepada lakilaki (suami) sebagaimana si suami mengkomunikasikannya dengan istri secara terbuka. Ini sebenarnya telah dicontohkan dalam rumah tanggan Nabi, sehingga Islam mudah diterima kaum perempuan saat itu, karena nampak lebih membela kepentiangan perempuan dibandingkan dengan budaya dan ajaran lain yang ada saat itu. ${ }^{43}$

Merubah pradigma memang sulit, tetapi harus terus diupayakan. Karena semua umat Muslim sepakat bahwa syarî'ah adalah hukum Allah untuk kemaslahatan umat manusia. ${ }^{4}$ Syarî'ah sudah lengkap, sempurna, universal berlaku sepanjang zaman, dan oleh karena itu tidak bisa hanya dipahami seperti kita memahaminya saat ini, tetapi terus memerlukan interpretasi yang berkesinambungan. 45

Memang dewasa ini kita sering dihadapakan dengan mereka yang disebut dengan neo Konservatif. ${ }^{46}$ Mereka memandang bahwa perempuan harus dibedakan dengan laki-laki, karena memang kodrat dan takdirnya begitu. Wacana ini harus ditolak karena kenyataannya perempauan banyak yang memiliki kelebihan dibandingkan laki-laki baik di dalam rumah tangga maupun dalam karir sosial sebagaimana peran ganda tersebut di atas. ${ }^{47}$

Sebaliknya kritik Muslim Progressive pada golongan neo Konservatif ini adalah penguasaan bahasa yang sangat miskin dan terbatas. Sehingga tidak mampu melahirkan konsep figh sebagai interpretasi syarî'ah yang ramah lingkungan dan mampu beradaptasi

43 Scott Sirajul Haq Kugle, "Sexuality, Diversity, and Ethics in the Agenda of Progressive Muslim" dalam Muslim Progressive, ed. Safi hlm. 190-191.

${ }^{44}$ Ghada Karm, "Perempuan, Islam, dan Patriarkalisme" dalam Feminisme dan Islam, ed. Mai Yamani, hlm. 105.

${ }^{45}$ Ali, "Progressive Muslim", hlm. 167.

46 Golongan ini dengan wajah yang baru berorientasi mengembalikan kajian keislaman seperti apa adanya dalam teks. Tidak boleh ada interpretasi apa pun di luar bunyi teks hukum. Tokoh gerakan ini saat ini yang muncul adalah Shâlih Ibn Ghanim al-Sadlân, seorang professor syarîah di Muhammad Ibn Saud Islamic University Riyadl. Ibid., hlm.173.

47 Ibid., hlm. 172-175. 
dengan waktu. 48 Pendek kata, dalam pandangan Muslim Progressive teks harus ditafsirkan dan dipahami dengan orientasi kemaslahatan umat manusia (rahmah li al-'âlamîn). ${ }^{49}$

Sekali lagi harus dikatakan bahwa memang sulit mengubah paradigma. Oleh karena itu, kita yang sudah berusaha untuk menjadi progresif harus terus mengupayakan, meskipun di sana sini banyak ditemukan kendala. Kalau ditarik pada kondisi riil masyarakat Indonesia saat ini, setidaknya kita dapat memetakan ada beberapa problem besar untuk mengubah paradigma tersebut. Kendalakendala tersebut di antaranya adalah: Pertama, kesenjangan pendidikan antara laki-laki dengan perempuan. Memang pada level pendidikan dasar dan menengah hal ini sepertinya tidak dirasakan sebagai masalah. Akan tetapi kalau diamati pada tataran pendidikan tinggi apalagi setingkat program doktor, maka akan nampak sangat jelas perbandingan antara mahasiswa laki-laki dan perempuan. Hal in dikarenakan pemberian kesempatan bagi kaum perempuan, setidaknya oleh suami dan keluarga besarnya tidak sebesar dengan apa yang diberikan pada laki-laki (oleh istri) dan keluarganya. Padahal kita tahu bahwa keberhasilan pendidikan menjadi kunci keberhasilan rumah tangga, dan pada gilirannya akan mengantarkan pada keberhasilan masyarakat dan kesejahteraan kehidupan berbangsa yang lebih luas.

Kedua, kita sulit mengubah paradigma kurikulum pendidikan, dikarenakan pendidikan kita masih banyak mengalami problema filosofis, di antaranya masih sangat lengket dan terikat dengan politik. Perubahan sosial (social change) termasuk dalam pendidikan sulit diwujudkan, jika politik yang notabene sarat dengan kepentingan dan berujung pada kemenangan satu golongan dan kekalahan yang lain, masih menyertai perumusan kebijakan penidikan yang semestinya berpijak pada kepentingan bersama.

Ketiga, pemahaman yang salah tentang kesetaraan jender. Paradigma kesetaraan jender sering disalahtafsirkan dengan penghapusan kodrat dan ruang privat perempuan. Sering juga jender

\footnotetext{
48 Ibid., hlm. 180.

${ }^{49}$ Gwendolyn Zaharoh Simmon, "Are We Up To Challenge? The Need for a Radical Re-Ordering of the Islamic Discourse on Women" dalam Muslim Progressive, ed. Safi, hlm. 239.
} 
dikonotasikan sama dengan seks yang tabu dibicarakan dan cenderung harus dikendalikan. Sejatinya, jender harus dipahami dengan posisi perempuan dalam konteks sosial yang memiliki kesempatan yang sama di ruang public untuk berperan, berdaya guna, membangun, berkreasi, berimajinasi, dan sebagainya.

Kendala-kendala tersebut akan senantiasa menyertai upaya penyetaraan jender. Namun usaha untuk meminimalisasi kendala tersebut juga harus terus diupayakan. Beberapa upaya (alternative action) untuk itu dapat dilakukan diantaranya dengan hal-hal berikut: (1) Pemberdayaan perempuan dalam berbagai peran sosial, semisal pendidikan, kesenian, keagamaan, budaya, politik, hukum dan seterusnya; (2) pemberian akses yang sama atara laki-laki dan perempuan dalam pengembangan diri, semisal dalam menempuh pendidikan tinggi, dan sebagainya; (3) pemberian fasilitas yang sama antara laki-laki dan perempuan; (4) partisipasi yang aktif harus diperankan oleh kaum perempuan, dalam hal ini perempuan harus mengambil inisiatif untuk memerankan dirinya dalam ruang publik; (5) penyediaan anggaran (budged) yang cukup dan seimbang antara kepentingan laki-laki dan perempuan.

Progresifitas umat Muslim memang tidak bisa didapatkan secara instant, melainkan memerlukan proses yang panjang, khususnya dalam mengawal kesetaraan jender. Proses tersebut harus sudah dimulai saat ini, oleh kita dan dengan upaya yang tentu saja semampu yang kita bisa.

\section{Penutup}

Memahami Muslim Progressive dengan ketiga agenda utamanya, yakni mewujudkan keadilan sosial, mengkampanyekan kesetaraan jender, dan memahami pulralisme, seakan-akan kita memasuki harapan baru dengan lahirnya Islam yang ramah lingkungan, humanis, toleran (tasâmuh), moderat (tawâssuth), seimbang (tawâzun), dan seterusnya. Paham keislaman yang kita yakini mampu menengahi paham Islam radikal fundamental (dalam bahasa Omid Safi disebut ultra Konservatif dan neo Konservatif) di satu sisi, dan Islam liberal bahkan Islam sekular di sisi yang lain. Kedua sisi itu seakan ditakdirkan untuk saling menjauh dan saling mengklaim sebagai Islam yang paling benar. Muslim Progressive hadir menawarkan diri untuk berada di antara keduanya, serta mencoba 
untuk mempertemukan keduanya dengan menarik isu keadilan sosial, kesetaraan jender dan pluralisme sebagai agenda bersama Islam yang besar berwibawa dan penuh kedamaian.

\section{Daftar Pustaka:}

al-Faruqi, Isma'il Raji. al-Tawhid: Its Implications for Thought and Life. Riyadl: International Islamic Publishing House, 1995.

Ali, Kecia. "Progressive Muslim and Islamic Jurisprudence: The Necessity for Critical Engagement with Marriage and Devorce Law," dalam Muslim Progressive on Justice, Gender and Pluralism. Ed. Omid Safi. Oxford: Oneworld, 2003.

Boerenbeker, E.A. "Wanita dalam Hukum Waris Adat," dalam Peranan dan Kedudukan Wanita Indonesia. Ed. Maria Ulfah Subardio dan T.O. Ihromi. Yogyakarta: Gajahmada University Press, 1994.

Karm, Ghada. "Perempuan, Islam, dan Patriarkalisme" dalam Feminisme dan Islam: Perspektif Hukum dan Sastra. Ed. Mai Yamani, terj. Purwanto. Jakarta: Nuansa, 2000.

Kugle, Scott Sirajul Haq. "Sexuality, Diversity, and Ethics in The Agenda of Progresive Muslim" dalam Muslim Progressive on Justice, Gender and Pluralism. Ed. Omid Safi. Oxford: Oneworld, 2003.

Makdisi, Jean Said. "Mitologi Kemodernan: Perempuan dan Demokrasi di Lebanon," dalam Feminisme dan Islam: Perspektif Hukum dan Sastra. Ed. Mai Yamani, terj. Purwanto. Jakarta: Nuansa, 2000.

Marsod, Afaf Lutfi al-Sayyid. "Perempuan Wira Usaha," dalam Feminisme dan Islam: Perspektif Hukum dan Sastra. Ed. Mai Yamani, terj. Purwanto.Jakarta: Nuansa, 2000.

Moghadam, Valentine M. Modernizing Women: Gender and Social Change in The Middle East. Boulder dan London: Lynne Rienner Publisher, 1993.

Moosa, Ebrahim. "Transitions in the Progress of Civilization: Theorizing History, Practice, and Tradition", dalam Voices of Change. Eds. Vincent Cornell dan Omid Safi. Westport: Praeger Publisher, 2007. 
Safi, Omid. "Challenges and Oppuortunities for the Progressive Muslim in North America", Muslim Public Affairs Journal (Januari 2006).

Safi, Omid. "I and Thou in a Fluid Wordl: Beyond Islam versus the West" dalam Voice of Change. Eds. Vincent Cornell and Omid Safi. Westport: Praeger Publisher, 2007.

Safi, Omid. "Introduction: The Time They Are A Changing- A Muslim Quest for Justice, Gender Equality, and Pluralism", dalam Muslim Progressive on Justice, Gender and Pluralism. Ed. Omid Safi. Oxford: Oneworld, 2003.

Safi, Omid. "Progressive Islam in America." Transkrip wawancara dengan Krista Tippet dalam Speaking of Faith, 28 Juli 2005.

Saptari, Ratna dan Holzner, Brigitte. Perempuan Kerja dan Perubahan Sosial: Sebuah Pengantar Studi Perempuan. Jakarta: Pustaka Utama Grafiti, 1997.

Shaik, Sa'diyyya. "Transforming Feminism: Islam, Women, and Gender Justice" dalam Muslim Progressive on Justice, Gender and Pluralism. Ed. Omid Safi. Oxford: Oneworld, 2003.

Shihab, Alwi. Islam Inklusif: Menuju Sikap Terbuka dalam Beragama. Bandung: Mizan, 1999.

Simmon, Gwendolyn Zaharoh. "Are We Up To Challenge? The Need for A Radical Re-Ordering of the Islamic Discourse on Women." dalam Muslim Progressive on Justice, Gender and Pluralism. Ed. Omid Safi. Oxford: Oneworld, 2003.

Watt, William Montgomery. Islamic Fundamentalism and Modernity. London dan New York: Routledge, 1988.

Wolf, Naomi. Geger Gender. Terj. Omi Intan Naomi. Yogyakarta: Pustaka Semesta Press, 1999.

www.haffingtonepost.com./omed-safi. diakses 5 Oktober 2012

www.religionnews.com//../omidsafi. diakses 5 Oktober 2012

www.religionnews.com//../omidsafi. diakses 5 Oktober 2012. 